\title{
LIETUVOS VISUOMENĖS SVEIKATINIMO PER SPORTĄ POLITIKOS İGYVENDINIMO AKTUALIJOS „EUROPOS SĄJUNGOS FIZINIO AKTYVUMO GAIRIŲ“ KONTEKSTE
}

\author{
Vilma Čingienè \\ Mykolo Romerio universiteto Politikos ir vadybos fakulteto \\ Vadybos institutas \\ Valakupių g. 5, LT-10101 Vilnius, Lietuva \\ Telefonas (+370 52) 740610 \\ Elektroninis paštas v.cingiene@mruni.eu
}

\begin{abstract}
Skaistè Laskienè
Lietuvos sveikatos mokslų universiteto Visuomenès sveikatos fakulteto Socialinių ir humanitarinių mokslų katedra

Šiaures pr. 57, LT-49264 Kaunas, Lietuva

Telefonas (+370 37) 327233

Elektroninis paštas skaiste_kaunas@hotmail.com

Pateikta 2014 m. sausio 27 d., parengta spausdinti 2014 m. kovo 7 d.
\end{abstract}

$$
\text { doi:10.13165/SPV-14-1-6-08 }
$$

\section{Santrauka}

Straipsnyje analizuojama Europos Komisijos inicijuoto dokumento „ES fizinio aktyvumo gaires" (2008) igyvendinimo situacija Lietuvoje. Sveikatinamasis fizinis aktyvumas yra svarbi Europos sporto politikos sudedamoji dalis. Atlikto empirinio tyrimo rezultatai sveikatos, švietimo ir sporto ekspertu vertinimu parode, kad, realizuojant Lietuvoje visuomenés sveikatinimo per sporta politika, susiduriama su menku tarpsektoriniu bendradarbiavimu, pasireiškiančiu tinkamos infrastruktūros, būtinu finansiniu ir žmogiškųju ištekliu stoka. Nepakanka informacijos apie Lietuvoje vykdomas visuomenes sveikatinimo per fizine veikla programas. Didžiausias visuomenés sveikatinimo per sporta programu vykdymo trūkumas - tai pasyvus ju vykdymas tiek dèl finansiniu ištekliu stokos, tiek dèl susiformavusio netinkamo valdžios instituciju požiūrio ị visuomenès sveikatinimo per sportą bütinybę, galimybes ir perspektyvas.

Reikšminiai žodžiai: sveikatinamasis fizinis aktyvumas, sveikatinimas per sportą, sporto politika.

1 ES fizinio aktyvumo gairès, 2008 [interaktyvus]. [žiūrèta 2013-12-15]. <http://ec.europa.eu/sport/ library/doc/c1/pa_guidelines_4th_consolidated_draft_en.pdf $>$. 


\section{İvadas}

„ES fizinio aktyvumo gairèse” $(2008)^{2}$ rekomenduojami politiniai veiksmai, skirti remti sveikatą gerinantị fizini aktyvumą. Dokumente nurodoma, jog svarbu, kad Europos Sąjungos (toliau - ES) valstybès narès parengtų nacionalinius fizinio aktyvumo skatinimo planus, siekdamos pakeisti nesveikus gyvensenos ịpročius ir padèti visuomenei suvokti fizinio aktyvumo naudą sveikatai. Šiame dokumente sutelkiamas dėmesys ị žinomų Pasaulio sveikatos organizacijos (toliau - PSO) rekomendacijų dèl fizinio aktyvumo igyvendinimą; tai yra praktinio pobūdžio dokumentas, kuriame keliamas tik fizinio aktyvumo klausimas (nekalbama apie mitybą ar kitas susijusias temas). Gairès skirtos labai ịvairiems naudotojams, dirbantiems fizinio aktyvumo srityje. Pabrèžiama, kad „valstybių planai turètų atitikti jų teritorijų aplinkos sąlygas, visuomenès papročius ir kultūrą" (2008) ${ }^{3}$. Kai kurios ES valstybès (Prancūzija, Vokietija, Liuksemburgas, Slovėnija, Jungtinè Karalystė, Suomija) narės yra parengusios nacionalines fizinio aktyvumo gaires, pagal kurias valstybès įstaigos ir privačios organizacijos bendradarbiaudamos skatina fizinį aktyvumą. Šiomis fizinio aktyvumo gairèmis dažnai remiamasi valstybės lèšomis finansuojant projektus, kuriais žmonès skatinami daugiau judèti.

Gairès skirtos viešojo ir privataus sektorių subjektams, priimantiems sprendimus visais (Europos, nacionaliniu, regioniniu ir vietos) lygmenimis. Jose patvirtintas PSO požiūris ir stengtasi patarti, kaip reikètų siekti tikslų konkrečiais veiksmais.

Lietuva, būdama PSO nare ir ES nare, pripažįsta esamas problemas ir siekia prisijungti prie inicijuojamų veiksmų. Kyla klausimas: kaip šalyje yra suvokiamos bei realizuojamos sveikatą stiprinančios fizinio aktyvumo nuostatos, koks gyventojų fizinio aktyvumo lygis ir kaip suprantamos bei realizuojamos ES fizinio aktyvumo gairès?

Straipsnio tikslas - atskleisti Lietuvos visuomenès sveikatinimo per sportą politikos igyvendinimo aktualijas „ES fizinio aktyvumo gairių“ kontekste.

Tyrimo objektas - Lietuvos visuomenės sveikatinimo per sportą politikos igyvendinimo aktualijos „ES fizinio aktyvumo gairių“ kontekste.

\section{Tyrimo metodai ir organizavimas: mokslinès literatūros analizé, dokumentų turinio analizè, struktūrizuotas interviu}

Tyrimo organizavimas. Tyrimo tikslui pasiekti pasirinktas kokybinis tyrimas, atliktas naudojant struktūrizuotą interviu. Tyrimo metu buvo apklausiami sveikatos, švietimo ir sporto sektoriaus ekspertai. Šie sektoriai pasirinkti atsižvelgiant ị nagrinètus dokumentus, kuriuose nurodoma, jog igyvendinant visuomenés sveikatinimo per sportą politiką šie trys sektoriai turi didžiausią reikšmę. Ypatingai daug dèmesio šių trijų sektorių bendradarbiavimui skiriama „ES fizinio aktyvumo gairèse“ $(2008)^{4}$.

Tiriamoji grupè ir atranka. Tyrime apklausti sveikatos, švietimo ir sporto sričiu ekspertai, dirbantys Panevėžio bei Kauno miestų savivaldybėms pavaldžiose įstaigose. Visi apklaustieji turi aukštąji išsilavinimą, keturi iš šešių respondentų aukštąji išsilavinimą igiję Lietuvos kūno kultūros akademijoje (dabar Lietuvos sporto universitetas), kiti du apklaustieji - Šiaulių universitete ir Kauno medicinos universitete (dabar Lietuvos sveikatos mokslų universitetas). Du yra ịgiję magistro laipsnius visuomenės sveikatos srityje. Pusẻ apklaustųjų

ES fizinio aktyvumo gairès, 2008, supra note 1 .

Ibid.,p. 4.

ES fizinio aktyvumo gairès, 2008, supra note 1. 
užima vyriausiojo specialisto pareigas, kiti - sveikatospriežiūros specialisto, direktoriaus bei metodininko pareigas. Respondentų amžiaus vidurkis - 42,16 metai, vyriausias respondentas yra 60 metų amžiaus, jauniausias 25 metų amžiaus. Einamų pareigų darbo patirties vidurkis - 8,16 metai, didžiausia darbo patirtis - 20 metų, trumpiausia -2 metai.

Tyrimo eiga. Tyrimas vyko $2011 \mathrm{~m}$. balandžio 13-15 dienomis. Interviu buvo pravesti respondentams patogiu metu jų pasirinktoje vietoje: su penkiais iš šešių respondentų interviu vyko jų darbo vietose.

\section{Tyrimo rezultatai}

\subsection{Europos Sąjungos sveikatą stiprinančio fizinio aktyvumo politikos reglamentavimas ir igyvendinimas}

Tarybos rekomendacija dèl sveikatinamojo fizinio aktyvumo skatinimo įvairiuose sektoriuose $(2013)^{5}$ grindžiama $2011 \mathrm{~m}$. komunikato „ES lygmens veiksmų sporto sektoriuje svarbos didinimas" tvirtinimu, kad fizinis aktyvumas yra vienas svarbiausių sveikatai veiksnių šiuolaikinejje visuomenèje ir kad sportas yra esminè visos viešosios politikos strategijos, skirtos fiziniam aktyvumui didinti, dalis. Komisija ir valstybės narès „remdamosi „ES fizinio aktyvumo gairemis“ $(2008)^{6}$ toliau dès pastangas rengiant nacionalines gaires, ịskaitant peržiūros ir koordinavimo procesą“. Šios pagrịstą mokslinę nuomonę iš esmès atitinkančios gairès, kurias parengè 22 įvairių sričių ekspertų iš visos Europos grupè, $2008 \mathrm{~m}$. buvo patvirtintos ES politiniu lygmeniu. Jose pakartotos PSO rekomendacijos dèl būtino fizinio aktyvumo, pabrèžta, kaip svarbu vadovautis tarpsektoriniu požiūriu, ir pateikta 41 konkreti veiklos gairè. Šiame poveikio vertinime nustatyti ir išanalizuoti svarbiausi veiksniai, nuo kurių priklauso planuojama ES politikos iniciatyva dèl sveikatinamojo fizinio aktyvumo (toliau - SFA), pagrịsta ES fizinio aktyvumo gairèmis (toliau - ES FAG). Pripažistama, kad „sveikatinamojo fizinio aktyvumo koncepcija yra gana nauja dalykinè sritis, kurioje vyksta sparti mokslo pažanga ir kuri aprẻpia tiek fizinị aktyvumą, glaudžiai susijusị su sportu ir fiziniais pratimais, tiek visuomenès sveikatą". SFA daug dèmesio skiria Pasaulio sveikatos organizacija, ypač pagal savo $2004 \mathrm{~m}$. Pasaulinę mitybos, fizinio aktyvumo ir sveikatos strategiją. Pabréžiama, kad „sèkmingas SFA skatinimas daugiausia priklauso nuo valstybèse narèse dedamų pastangų“. Vis aiškiau suvokiant, koks svarbus yra SFA, daugelis valdžios institucijų labiau stengiasi ji skatinti. ES taip pat skiria dèmesio fiziniam aktyvumui savo politika ir veiksmais sporto srityje (pvz., Baltoji knyga dèl sporto, 20077; ES fizinio aktyvumo gairès (ES FAG), 2008 ${ }^{8}$; Komunikatas dèl sporto, $2011^{9}$ ) ir sveikatos srityje (pvz., Baltoji knyga dèl Europos strategijos su mityba, antsvoriu ir nutukimu susijusioms sveikatos problemoms spręsti, 2007) ${ }^{10}$. Naudodamasi atitinkamomis ES lygmens politikos koordinavimo sistemo-

Tarybos rekomendacija dèl sveikatinamojo fizinio aktyvumo skatinimo įvairiuose sektoriuose, 2013 [interaktyvus]. [žiūrèta 2013-12-15].<http://ec.europa.eu/sport/library/documents/c1/com2013-603-final-council-recommendation-hepa_lt.pdf >.

6 ES fizinio aktyvumo gairès, 2008, supra note 1.

7 Europos Komisija. „Baltoji knyga dèl sporto“, 2007 [interaktyvus]. [žiūrèta 2013-12-02]. <http:// ec.europa.eu/dgs/education_culture/publ/pdf/sport/whitepaper_lt.pdf $>$.

$8 \quad$ ES fizinio aktyvumo gairès, 2008, supra note 1.

9 Developing the European Dimension in Sport,2011[interaktyvus]. [žiūrèta 2013-12-20]. <http:// ec.europa.eu/sport/news/communication-on-sport-adopted_en.htm>.

10 Baltoji knyga dèl Europos strategijos su mityba, antsvoriu ir nutukimu susijusioms sveikatos problemoms spręsti. (2007). 2010/C 8 E/18. Briuselis: Europos Sajungos oficialus leidinys 
mis, visų pirma Sporto, sveikatos ir dalyvavimo ekspertų grupe, kurią sudaré Taryba pagal 2011-2014 m. ES darbo planą sporto srityje ${ }^{11}$, ir Mitybos ir fizinio aktyvumo aukšto lygio darbo grupe (toliau - aukšto lygio darbo grupe), sudaryta pagal minètą $2007 \mathrm{~m}$. strategiją siekiant padèti valstybèms narèms dalyvauti koordinuojamoje veikloje ir dalytis informacija apie politiką, politines idejas ir praktiką.

Siekiant sèkmingai igyvendinti numatytus tikslus Europos Komisija 2011 m. parengiamųjų veiksmų plane išskyrė keturis prioritetus, vienas jų - skatinti sveikatinamąji fizinị aktyvumą, todèl buvo finansuoti 9 (iš 18) projektai (žr. 1 lentelę).

1 lentelè. Finansavimą gavusios organizacijos, projektų pavadinimas ir paramos suma

\begin{tabular}{|c|c|c|c|}
\hline $\begin{array}{l}\text { Eil. } \\
\text { Nr. }\end{array}$ & Šalis /organizacija & Projekto pavadinimas & $\begin{array}{c}\text { Paramos suma } \\
\text { (EUR) }\end{array}$ \\
\hline 1. & Vokietija & $\begin{array}{l}\text { "You need exercise! Introducing every day culture of } \\
\text { sports" } \\
\text { "Healthy children in sound communit(ies)" }\end{array}$ & $\begin{array}{l}210649,00 \\
280000,00 \\
\end{array}$ \\
\hline 2. & Ispanija & "Euro sport health" & 220000,00 \\
\hline 3. & Suomija & "Sport clubs for health (scforh)" & 72704,00 \\
\hline 4. & Prancūzija & "Athle-sante" & 230000,00 \\
\hline 5. & $\begin{array}{l}\text { PSO Europos regiono } \\
\text { biuras }\end{array}$ & "Net-sport-health" & 256666,00 \\
\hline 6. & $\begin{array}{l}\text { Tarptautinè sporto ir kul- } \\
\text { tūros asociacija (ISCA) }\end{array}$ & "Sante" (sport action network of europe) & 295832,00 \\
\hline 7. & $\begin{array}{l}\text { Europos sveikatos ir fitne- } \\
\text { so asociacija (EHFA) }\end{array}$ & $\begin{array}{l}\text { "Becoming the hub: the health and fitness sector and } \\
\text { the future of health enhancing physical activity" }\end{array}$ & 179997,00 \\
\hline 8. & $\begin{array}{l}\text { Regioniné Extramadūros } \\
\text { jaunimo ir sporto minis- } \\
\text { terija }\end{array}$ & "S²-port" & 230575,58 \\
\hline
\end{tabular}

Šaltinis: http://ec.europa.eu/sport/

2012 m. lapkričio mèn. Komisija pripažino tolesnị sveikatinamąji fizinio aktyvumo skatinimo poreikị ir pasiūlè Europos Tarybai rekomendacijas dèl sveikatinamojo fizinio aktyvumo vertinimo sandaros remiantis ES FAG numatytais tam tikrais kriterijais įvardintoms svarbiausioms tarpsektorinèms sritims.

Lietuvai pirmininkaujant Europos Sąjungos Tarybai, 2013 m. lapkričio mèn. Briuselyje vykusiame ES Sporto tarybos posėdyje buvo priimti abu prioritetiniai Lietuvos dokumentai sporto srityje - Tarybos rekomendacija, skatinanti sveikatą gerinanti fizini aktyvumą, bei Tarybos išvados dèl sporto indèlio ị ES ekonomiką, kuriose ypač akcentuojamas sporto vaidmuo sprendžiant jaunimo nedarbo ir socialinès įtraukties problemas. Priimta Tarybos rekomendacija dèl sveikatinančio fizinio aktyvumo (angl. HEPA - Health enhancing physical activity) skatinimo - tai pirmas ES teisinis dokumentas sporto srityje, kuriame numatytas stebėsenos mechanizmas, veiksiantis suderintai su jau vykdomu Pasaulio sveikatos organizacijos fizinio aktyvumo ir mitybos monitoringu. Ši priemone padès sukaupti išsamesnę in-

11 Rezoliucija dèl 2011-2014 m. Europos Sajungos darbo plano sporto srityje, 2011 [interaktyvus]. [žiūrèta 2013-12-20].<http://eurlex.europa.eu/LexUriServ/LexUriServ.do?uri=OJ:C:2011:162:0001:0 005:LT:PDF>. 
formaciją apie šalyse narèse vykdomą pažangą siekiant skatinti visuomenès fizinį aktyvumą ir priimti kompetentingus politinius sprendimus.

\subsection{Lietuvos gyventojų fizinio aktyvumo tendencijos}

Informacija apie fizinį Lietuvos gyventojų aktyvumą - sportavimo bei aktyvios fizinès veiklos dažní, pateikiama Kūno kultūros ir sporto departamento prie Lietuvos Respublikos Vyriausybėsužsakymu atlikto Lietuvos gyventojų (15-74 metų Lietuvos gyventojai) fizinio aktyvumo tyrimo ataskaitoje (2013) ${ }^{12}$.

Tyrimo ataskaitoje teigiama, jog lyginant 201301 ir 201311 duomenis, stebimas 12 procentinių punktų sumažejęs sportuojančiųjų, besimankštinančiųjų skaičius. Reikšmingai dažniau sportuoja arba mankštinasi jaunesnio amžiaus respondentai (15-24 m.), igiję aukštąji išsilavinimą, nevedę, netekejjusios, tarnautojai, moksleiviai, studentai bei didmiesčiu gyventojai (per 150000 gyv.). Reikšmingai dažniau nesimankština ir nelanko jokių sporto pratybų 45-74 m. amžiaus grupès respondentai, vidurinio išsilavinimo asmenys, asmenys, kurių vidutinės vieno šeimos nario pajamos per mėnesị siekia 601-800 Lt, vedę, ištekèjusios, taip pat išsiskyrę, išsiskyrusios, darbininkai, ūkininkai, pensininkai, bedarbiai, kaimiškųjų vietovių gyventojai (iki 2000 gyv.). Tyrimo ataskaitoje konstatuojama, jog analizuojant mankštinimąsi / sportavimą sporto/sveikatingumo klube ir / ar fitneso centre, paaiškejo, jog penktadalis (22 proc.) apklausos dalyvių nurode, jog sportuoja aktyviai, reguliariai, daugiau nei pusè (62 proc.) teigè, jog niekada nesportuoja, nesimankština sporto, sveikatingumo klube ar fitneso centre. Reikšmingai dažniau 1-2 kartus per savaitę sportuoja 35-44 m. amžiaus respondentai, reikšmingai dažniau sportuoja, mankštinasi sporto, sveikatingumo klube ar fitneso centre vyrai (35-45 m.), gaunantieji dideles pajamas (1000 Lt ir daugiau vienam šeimos nariui), vadovai, įmonès savininkai.

Reikšmingai dažniau 3-4 kartus per savaitę savivaldybės sporto mokykloje ar/ir sporto centre sportuoja/mankštinasi pradinị / pagrindinị išsilavinimą igiję respondentai. 1-2 kartus per savaitę - kaimiškųjų vietovių gyventojai (iki 2000 gyv.). Bendrai vertinant sportavimą bendrojo lavinimo mokyklose išryškejja, kad reikšmingai dažniau čia sportuoja jaunesnio amžiaus respondentai (15-24 m.), žemų pajamų asmenys (iki 600 Lt vienam šeimos nariui), nedirbantieji, moksleiviai/studentai, nevedę/netekejjusios bei seniūnijų ir rajoninių centrų gyventojai (iki 2000 gyv. ir 2000-20 000 gyv.).

Tyrimo ataskaitoje paminèta, jog sportuojantys, besimankštinantys respondentai dažniausiai fizine veikla užsiima kitur (71 proc.). Daugiau nei pusė (54 proc.) respondentų sportuoja, mankštinasi kitur aktyviai, reguliariai, 17 proc.- retkarčiais; 5 kartus ir dažniau per savaitę kitur reikšmingai dažniau renkasi sportuoti 55-74 m. amžiaus grupès respondentai, pensininkai.

Lyginant 201301 ir 201311 tyrimų rezultatus, paaiškejjo, kad 201311 laikotarpiu šešiais procentiniais punktais išaugo užsiimančių kita aktyvia fizine veikla 5 kartus per savaitę ir dažniau; penkiais procentiniais punktais išaugo tris keturis kartus per savaitę užsiimančių kita aktyvia fizine veikla skaičius; vieną du kartus per savaitę kita aktyvia fizine veikla užsiimančiųjų skaičius taip pat išaugo penkiais procentiniais punktais. Vieną du kartus per savaitę reikšmingai dažniau kita aktyvia fizine veikla užsiima 15-24 m. amžiaus grupès respondentai, taip pat moksleiviai, studentai bei didmiesčių gyventojai (per 150000 gyv.). 5 kartus per savaitę ir dažniau kita aktyvia fizine veikla dažniau užsiima mažas pajamas gaunantys

12 Lietuvos gyventojų fizinio aktyvumo tyrimas, 2013 [interaktyvus].[žiūrèta 2013-12-25]. <http://www. kksd.lt/index.php?1590309353>. 
respondentai (iki 600 Lt vienam šeimos nariui), darbininkai, ūkininkai bei kaimiškųjų vietovių gyventojai (iki 2000 gyv.), niekada kita aktyvia fizine veikla neužsiima reikšmingai dažniau vyresnio amžiaus asmenys (65-74 m.), pensininkai bei mažesnių vietovių gyventojai (2000-20 000 gyv.).

\subsection{Tyrimo rezultatai}

Tyrimo rezultatai atskleidè trijų sektorių sveikatos, švietimo ir sporto atstovų nuomonę/ požiūrị ị sveikatinamojo fizinio aktyvumo skatinimo situaciją šalyje.

Sveikatos ir švietimo sektoriaus respondentų nuomone, didžiausias probleminis klausimas Lietuvoje igyvendinant sveikatinimo per sportą politiką yra infrastruktūros bei finansinių išteklių trūkumas ir paslaugų prieinamumas. Sveikatos sektoriaus atstovai pažymi ir žmoniu abejingumo problemą.

Gauti interviu atsakymai patvirtina Kūno kultūros ir sporto departamento užsakymu atlikto tyrimo „Lietuvos 7-80 metų amžiaus gyventojų požiūris ị kūno kultūros pratybas ir dalyvavimas jose“ (2007 ir 2011) rezultatus. Respondentai, atsakydami ị klausimą, „Su kokiomis problemomis susiduriate mankštindamasis savarankiškai?“, nurodè, jog arti nèra sporto aikštelių, bėgimo trasų ir kt., beveik 22 proc. $(2007)^{13}$ ir beveik 19 proc. $(2011)^{14}$. Galima teigti, jog infrastruktūros trūkumo problemą ižžvelgia ne tik specialistai, dirbantys šioje srityje, bet ir Lietuvos gyventojai.

Sporto sektoriaus atstovai turejjo kiek kitokią nuomonę. Jų teigimu, Lietuvos ir Europos probleminiai klausimai igyvendinant fizinio aktyvumo per sportą politiką nuo Europos skiriasi tuo, jog Lietuvoje valdžios institucijos per mažai dèmesio skiria šiai sričiai, taip pat neefektyviai veikia nevyriausybines organizacijos. Vienas respondentas paminejo informacijos sklaidos stoką. Tikslinga pažymèti, jog minètos problemos buvo keliamos rengiant tiek „Lietuvos gyventojų 2008-2012 m. fizinio aktyvumo skatinimo strategiją "15, tiek „Nacionalinę 2007-2015 metų sporto visiems programą“, kurios taip ir nebuvo priimtos.

Vertinant respondentų atsakymus ị antrąjị klausimą dẻl europiniais kriterijais grindžiamų Lietuvoje vykdomų visuomenès sveikatinimo programų, sveikatos ekspertų nuomonės išsiskyrè. Respondento $\mathrm{K}_{1}$ nuomone, programų vykdymo problema - jųtrumpalaikiškumas. Siekiant efektyviau igyvendinti programas jos turètų būti ilgalaikès ir tęstinès. Kito respondento $\left(\mathrm{P}_{1}\right)$ teigimu, projektus vykdyti - tikslinga, tik dèl projektų realizavimo situacija visuomenès sveikatinimo per sportą politikos srityje keičiasi teigiama linkme. Abu švietimo sektoriaus respondentai skirtingai vertino šalyje vykdomas visuomenès sveikatinimo programas. Pasak eksperto $\mathrm{P}_{2}$, programos yra vykdomos tik iš dalies, $\mathrm{o} \mathrm{K}_{2}$ priešingai - tvirtino, kad programos vykdomosgerai. Analizuojant sporto sektoriaus respondentų atsakymus paaiškejjo, kad jaučiamas žinių apie programas trūkumas ir vykdomos programos tik iš dalies igyvendinamos, nes stokojama darnaus programų igyvendinimo ir vertinimo mechanizmo.

Trečiuoju klausimu siekème išsiaiškinti priežastis, trukdančias igyventi visuomenès sveikatinimo per fizinę veiklą politiką. Materialinių ir žmogiškųjų išteklių (ypač kompeten-

13 Lietuvos 7-80 metų amžiaus gyventojų požiūrio ì kūno kultūros pratybas, sportą ir sportavimo ipročių tyrimo ataskaita, 2007 [interaktyvus]. [žiūrèta 2013-12-15]. <http://www.kksd.lt/index. php?1590309353>.

14 Lietuvos 7-80 metų amžiaus gyventojų požiūris ị kūno kultūros pratybas ir dalyvavimas jose, 2011 [interaktyvus]. [žiürèta 2013-12-15]. <http://www.kksd.lt/index.php?1590309353>.

15 Nacionalinès sporto visiems plètros programos rengimas, 2007 [interaktyvus]. [žiūrèta 2013-12-15]. $<$ http://www3.lrs.lt/pls/inter/w5_show?p_r=2025\&p_d=65445\&p_k=1>. 
cijos) trūkumą paminèjo visų sektorių respondentai. Sveikatos ir sporto sektoriaus atstovai pabrežè švietimo ir savišvietos stoką. Švietimo sektoriaus respondentas ịvardino sveikatinimo veiklos funkcijų dubliavimo trukdị, o sporto sektoriaus respondentas - kitą svarbų institucinị veiksnị - tarpsektorinio bendradarbiavimo trūkumą. Paminètos buvo ir kitos priežastys: laiko ir motyvacijos stoka, menkos sportavimo tradicijos, neefektyvi nevyriausybinių organizacijų veikla ir kt.

Analizuojant respondentų nuomonę dèl Lietuvoje priimamų visuomenès sveikatinimo per fizinę veiklą dokumentų ir jų privalumų bei trūkumų paaiškejo, jog, sveikatos sektoriaus atstovų nuomone, priimami dokumentai ne visada atsižvelgiant ị realia padètţ, švietimo sektoriaus atstovų - priimami dokumentai negali būti visiškai ígyvendinti, nes tam per silpna turima infrastruktūra ir galbūt Lietuvoje reiktų mažinti projektų skaičių, orientuojantis ị kokybę bei didinant finansavima, o sporto sektoriaus atstovų teigimu, yra neatsakingai igyvendinami priimami dokumentai. Būtina pažymèti, kad du ekspertai (sveikatos ir sporto) pripažino, kad nèra susipažinę su priimtais dokumentais. Vertinant igyvendinamų dokumentų trūkumus buvo paminèta jų pasyvus vykdymas, finansavimo stoka, biurokratizmas, apibrëžtumo ir tikslumo stoka, o privalumus - geros idejos, istatymo ịpareigojimas ir vaiku švietimas.

Tyrimo rezultatai atskleide priežastis, kurios turi įtakos Lietuvos institucijų, atsakingų už visuomenés sveikatinimą per sportą, pasyvumą, dalyvaujant tarptautiniuose projektuose. Sveikatos sektoriaus ir vieno sporto sektoriaus respondentų nuomonės sutapo, kad institucijos nèra pasyvios, tiesiog pagrindinis lemiamas veiksnys yra žmogiškųjų ištekliụ trūkumas. Tačiau kiti tyrimo respondentai pasyvumo priežastimi ịvardino finansinių išteklių stoką. Šios kategorijos yra tarpusavyje tiesiogiai susijusios, t. y. dèl finansinių išteklių trūkumo nèra samdoma papildomų ir reikalingos kompetencijos darbuotojų, o esami darbuotojai, tikètina, tinkamai neatlieka savo pareigų.

Visų trijų sektorių atstovai kritiškai vertina institucines galimybes dalyvauti tarptautiniuose projektuose. Viena vertus, pasyvumą lemia didžiule biurokratija, keblumai vykdant viešuosius pirkimus, kita - įstaigos neatitinka standartų, nes siekiančioms gauti Europos Sąjungos programų finansavimą yra keliami didžiuliai reikalavimai, trečia - atsakingų institucijų pasyvumas, netikejimas teigiamais poslinkiais ir abejingumas sporto sektoriui. Tik vienas švietimo sektoriaus respondentas teige, jog yra dirbama su programomis ir nèra jokio pasyvumo.

Respondentai ne tiktai vertino priežastis, kurios turi ịtakos Lietuvos institucijų, atsakingų už visuomenès sveikatinimą per sportą, pasyvumą, dalyvaujant tarptautiniuose projektuose, bet ir siūlè pasyvumo problemos sprendimo būdus. Vieno sveikatos ir vieno švietimo sektoriaus atstovų nuomone tikslinga būtų skatinti darbuotojus didinant jų motyvaciją. Antrasis švietimo sektoriaus respondentas nesutinka su kolegos nuomone, manydamas, jog motyvacijos užtenka, nes pasyvumui turi ịtakos biurokratija, t. y. norint mažinti darbuotojų pasyvumą, reikia mažinti biurokratiją. Kito sveikatos sektoriaus atstovo teigimu, reiktų ne tik skatinti esamus darbuotojus, bet galbūt keisti (esant papildomos kvalifikacijos ir kompetencijosporeikiui) ar išplèsti (ịvesti papildomus etatus) personalo sudètị sukuriant projektų rengejjo pareigybę.

Sporto sektoriaus atstovų nuomone, pasyvumo problemą reikia spręsti keičiant Lietuvoje susiformavusị netinkamą valdžios institucijų požiūrị i visuomenès sveikatinimą per sportą, kuris daro didelị neigiamą poveikị igyvendinant programas. Be to, akcentuojama tiek horizontalaus (tarp atsakingų ministerijų), tiek vertikalaus (tarp atsakingų ministerijų ir savivaldybių) tarpsektorinio bendradarbiavimo stoka. 


\section{Išvados}

Remiantis empirinio tyrimo rezultatais apie visuomenės sveikatinimo politikos per sportą igyvendinimą šalyje sveikatos, švietimo ir sporto ekspertų vertinimu galima teigti, kad:

1. Realizuojant Lietuvoje visuomenès sveikatinimo per sportą politiką, susiduriama su tarpsektorinio bendradarbiavimo stoka, pasireiškiančia tinkamos infrastruktūros, būtinų finansinių ir žmogiškųjų išteklių nepakankamumu.

2. Nepakanka informacijos apie Lietuvoje vykdomas visuomenès sveikatinimo per fizinę veiklą programas, todèl šalyje priimami visuomenès sveikatinimo per sportą veiklos dokumentai nèra tinkamai realizuojami.

3. Didžiausias visuomenès sveikatinimo per sportą programų vykdymo trūkumas - tai pasyvus jų vykdymas, galimai atsiradęs dèl valstybinių institucijų pasyvumo, atsiradusio tiek dèl finansinių išteklių stokos, tiek dèl susiformavusio netinkamo valdžios institucijų požiūrio i̇ visuomenès sveikatinimo per sportą būtinybę, galimybes ir perspektyvas.

\section{Literatūra}

1. Developing the European Dimension in Sport,2011[interaktyvus]. [žiūrèta 2013-12-20]. <http://ec.europa.eu/sport/news/communication-on-sport-adopted_en.htm>.

2. Baltoji knyga dèl Europos strategijos su mityba, antsvoriu ir nutukimu susijusioms sveikatos problemoms spręsti. (2007). 2010/C 8 E/18. Briuselis: Europos Sąjungos oficialus leidinys.

3. Europos Komisija. „Baltoji knyga dèl sporto“, 2007 [interaktyvus]. [žiūrèta 2013-12-02]. $<$ http://ec.europa.eu/dgs/education_culture/publ/pdf/sport/whitepaper_lt.pdf>.

4. European network for the promotion of health-enhancing physical activity [interaktyvus]. [žiūrèta 2013-12-20]. <http://www.euro.who.int/en/health-topics/disease-prevention/ physical-activity/activities/hepa-europe $>$.

5. ES fizinio aktyvumo gairès, 2008 [interaktyvus]. [žiūrèta 2013-12-15]. <http://ec.europa. eu/sport/library/doc/c1/pa_guidelines_4th_consolidated_draft_en.pdf $>$.

6. Lietuvos gyventojų fizinio aktyvumo tyrimas, 2013 [interaktyvus]. [žiūrèta 2013-12-25]. <http://www.kksd.lt/index.php?1590309353>.

7. Lietuvos 7-80 metų amžiaus gyventojų požiūrio ì kūno kultūros pratybas, sportą ir sportavimo ịpročių tyrimo ataskaita, 2002 [interaktyvus]. [žiūrèta 2013-12-15]. <http:// www.kksd.lt/index.php?1590309353>.

8. Lietuvos 7-80 metų amžiaus gyventojų požiūris ì kūno kultūros pratybas ir dalyvavimas jose, 2007 [interaktyvus]. [žiūrèta 2013-12-15].<http://www.kksd.lt/index. php?1590309353>.

9. Nacionalinès sporto visiems plètros programos rengimas, 2007 [interaktyvus]. [žiūrèta 2013-12-15]. <http://www3.lrs.lt/pls/inter/w5_show?p_r=2025\&p_d=65445\&p_k=1>.

10. Rezoliucija dèl 2011-2014 m. Europos Sąjungos darbo plano sporto srityje, 2011 [interaktyvus]. [žiūrèta 2013-12-20]. <http://eurlex.europa.eu/LexUriServ/LexUriServ.do ?uri=OJ:C:2011:162:0001:0005:LT:PDF>.

11. Tarybos rekomendacija dèl sveikatinamojo fizinio aktyvumo skatinimo ivairiuose sektoriuose, 2013 [interaktyvus]. [žiūrèta 2013-12-15].<http://ec.europa.eu/sport/library/ documents/c1/com-2013-603-final-council-recommendation-hepa_lt.pdf $>$. 


\title{
Actualities of Health Enhancing Physical Activity in Lithuanian Society in the Light of the EU Physical Activity Guidelines
}

\author{
Vilma Čingienė \\ Mykolas Romeris University, Lithuania \\ Skaistè Laskienè \\ Lithuanian University of Health Sciences, Lithuania
}

\section{Summary}

Background. Health Enhancing Physical Activity (HEPA) is an important component of European sports policy. Lithuania, a member of the WHO and the European Union, recognizes the existing problems and seeks to join the relevant initiatives. There are questions how the provisions of the Health Enhancing Physical Activity are perceived and realized, what is the level of physical activity among population, and how are the EU Physical Activity Guidelines followed and implemented. The aim of the article is to disclose the actualities of promoting health through sport and physical activity in Lithuanian society in the light of the EU Physical Activity Guidelines.

Research methods and organization. Analysis of scientific literature, content analysis of documents, structured interviews. Health, education and sports industry experts working in organizations and institutions reporting to Panevėzys and Kaunas local authorities were interviewed for the study. All subjects are persons with third-level education. Half of the interviewees hold senior specialist's position. The average age of the respondents is 42.16 years and the average work experience is 8.16 years. The survey was done in April, 2011.

Results and conclusions. The results of the empirical research on public health promotion in the country based on the evaluations of health, education and sports experts showed that implementation of HEPA policy is encumbered by inadequate cross-sector collaboration, which is also hindered by underdeveloped infrastructure and scarcity of indispensable financial and human resources. Information about HEPA programs in Lithuania is scant, and for this reason HEPA documents adopted in the country are not adequately executed. The biggest weakness of the HEPA programs is unreceptiveness, apparently caused by the inertness of the governmental institutions resulting from both inadequate funding and inappropriate approach of the authorities to the necessity, opportunities and perspectives of health enhancing physical activities.

Keywords: health enhancing physical activity, promoting health through sports, sports policy.

Vilma Čingienè, Doctor of Social Sciences, Mykolas Romeris University, Faculty of Policy and Management, Institute of Management, Professor. Research interests: The Development of Sport and active Leisure Sector in Europe; Evaluation of economic importance of sport.

Vilma Čingienė, Mykolo Romerio universiteto Politikos ir vadybos fakulteto Vadybos instituto profesorè, socialinių mokslų daktarè. Mokslinių tyrimų kryptys: sporto ir aktyvaus poilsio sektoriaus pletra Europoje; ekonominis sporto reikšmės vertinimas.

Skaistė Laskienė, Doctor of Philosophy Sciences, Lithuanian Health Sciencies University, Faculty of Public Health, Department of Humanities and Social Sciences, Assoc. Prof. Research interests: Research methodology: the possibilities of humanitarian paradigm in social research.

Skaistė Laskienė, Lietuvos sveikatos mokslų universiteto Visuomenès sveikatos fakulteto Socialinių ir humanitarinių mokslų katedros docentè, filosofijos mokslų daktarè. Mokslinių tyrimų kryptys: mokslinio tyrimo metodologija: humanitarinės paradigmos galimybės socialiniuose tyrimuose. 